\title{
Dimensions Of Entrepreneurial Activity: The Case Of Slovenia
}

Vlado Dimovski, (Email: vlado.dimovski@ef.uni-lj.si), University of Ljubljana, Slovenia Jana Žnidaršič, (Email: jana.znidarsic@ef.uni-lj.si), University of Ljubljana, Slovenia Sandra Penger, (Email: sandra.penger@ef.uni-lj.si), University of Ljubljana, Slovenia

\begin{abstract}
Even though the Slovenian economic development policy is forcing the development of fast-growing enterprises, there is still a significant gap between the vision of highly-developed entrepreneurship and Slovenian entrepreneurial reality. Increasing rate of environmental change, technological complexity, globalization and many other challenges of modern economy are continuously forcing the developed countries to seek comparative advantages mainly in their human resources - in the trained, educated, flexible and self-confident workforce. Well educated people, possessing entrepreneurial skills and characteristics are initiators of high-tech and dynamic entrepreneurship, which is without doubt the main factor of development. In spite of the fact that the Slovenian economic development policy is forcing the development of high-tech and knowledge-based enterprises, there is still the significant gap between the vision of highly-developed entrepreneurship and Slovenian entrepreneurial reality. Considering the fact, that Slovenia is still far away from ideal entrepreneurial society in which entrepreneurship is the way of life for the majority of its population, this paper discusses dimensions of entrepreneurial activity, the main obstacles of entrepreneurial activity in Slovenia and the following hypotheses: (1) Slovenia needs to expand its entrepreneurial activity, especially high-tech, knowledge-based and dynamic entrepreneurship to compete successfully on the European market, (2) entrepreneurial culture in Slovenia is rather low; the psychological profile of Slovenian entrepreneurs is closer to profile of employees than to dynamic entrepreneurs. As the entrepreneurial activity is a major feature showing the development of certain economy, the main aim of this study is to highlight the entrepreneurial activity in Slovenia and consequently to give suggestions for improving and developing current entrepreneurial situation. A vital task of the Slovenian entrepreneurial policy at the beginning of the 21st century is to set up a learning organization platform in small and medium enterprises, thus enabling their growth and sustainable comparative advantage. Moreover, the greatest challenge is to change the people's attitudes - building entrepreneurial culture in striving to move Slovenian economy towards the knowledge-based society.
\end{abstract}

\section{INTRODUCTION}

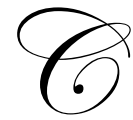

hallenges such as globalization and global competition, transition from industrial to new economy, technology and e-business, reorganization as well as the issues encompassing ethics, social responsibility, cultural differences, etc. clearly indicate the uncertainty of our future. Even unlimited amounts of goods and services cannot guarantee prosperity and material security to the citizens in any country or society.

Nowadays, human resource investment is the most crucial and basic investment, which enables further successful economic and social growth and development (Burton-Jones, 1999). Lifetime learning, continuous training and systematic development of entrepreneurial and managerial characteristics are becoming a basic need for any developed as well as developing country.

On the other hand, the crucial influence of entrepreneurship on growth, new job creation, innovation, and general prosperity (Birch, 1993; Smallbone, 1995) has been widely accepted, particularly in intellectual circles. While 
considering the significant gap between the vision of highly developed entrepreneurship and Slovenian entrepreneurial reality, we are going to discuss Slovenian entrepreneurial conditions more in detail.

This paper focuses on the comparison of entrepreneurial activity by country showing the slovenian entrepreneurial reality, aiming to establish weaknesses and give suggestions for improving and developing entrepreneurial activity in Slovenia.

\section{THE BENEFITS OF ENTREPRENEURIAL ACTIVITY}

Research studies have identified some crucial objectives that appeared to drive entrepreneurial policy at the national level: to increase competition, to strengthen the production chain, to diversify the economy, and to create employment and reduce unemployment (Smallbone, 1995). There are many other positive impacts of entrepreneurial activity (Birch in Možina et al., 1994; Bojović, 1989; Glas, 2000; OECD, 1998; Setnikar-Cankar, 1993; Vahčič, 2000; Vidovič-Tomanovič, 1999; Reynolds et al., 2001; EC 2003): discovering opportunities and their implementation, the contribution of entrepreneurial activity as a source of innovation and development of a diversified economic structure, the contribution of SME's as a "seed-bed" from which large companies can grow, enabling balanced regional development and the contribution of entrepreneurial activity to economic growth in general (costs are lower, productivity is higher, GDP expands, economic prosperity enables social and political stability).

\section{DIMENSIONS AND CONDITIONS OF ENTREPRENEURIAL ACTIVITY}

Global Entrepreneurship Monitor Analysis (Reynolds, Camp, Bygrave, Autio, Hay, 2001) has clearly demonstrated that the level of entrepreneurship varies from country to country. Entrepreneurship is a social phenomenon, which is influenced by different economic and non - economic conditions. Economic conditions include: access to profits, the existence of leading teams, opportunities, chances, capital and human resources, entrepreneurial education, etc. Non-economic factors can be grouped as non-economic motives (the need for achievement, the need for independence, dissatisfaction with the current job, the need for power and control over the situation), values (ethics, personal opinion, optimism, responsibility, honesty, rationality, etc.) and environmental factors (economic stability, open economy and free market, private ownership system, encouraging economic policy, developed entrepreneurial culture).

\section{ENTREPRENEURIAL ACTIVITY BY COUNTRY: INTERNATIONAL COMPARISON OF COUNTRIES INCLUDED IN THE GLOBAL ENTREPRENEURSHIP MONITOR (GEM) ANALYSIS}

The overall level of entrepreneurial activity for each country is represented by the TEA (Total Entrepreneurial Activity) index; the value shows the number per every 100 adult individuals who are trying to start a new firm or are the owners / managers of an active business less than 42 months old (Figure 1). TEA index shows total early-stage entrepreneurial activity, including "nascent entrepreneurs" who are starting business, and "new entrepreneurs" who own the firm not older than 42 months.

Figure 1 shows that there are significant differences between countries, reflecting economic and social development, as well as conditions influencing entrepreneurial activity in certain country. The TEA index varies from 1.48 percent in Japan up to 40.34 percent in Peru. The highest rate of early-stage entrepreneurial activity in Europe can be noticed in Iceland (13.57), central European countries on the other hand have much lower TEA index. It can be established that the Asian countries (Japan, Hong Kong and Singapore) form one rather homogenous group with an average prevalence rate of about 3.38 percent. In developing countries (Peru, Uganda, Ecuador, Jordan) the average is about 29 percent, Canada and the USA have an average prevalence rate of approximately 10 percent, two former British colonies (Australia and New Zealand) have an average more than 14 percent, and Latin American countries (Argentina, Brazil) have an average rate of 13.16 percent (Figure 1). 
Figure 1: Necessity And Opportunity-Based Entrepreneurial Activity By Country (TEA Index 2004)

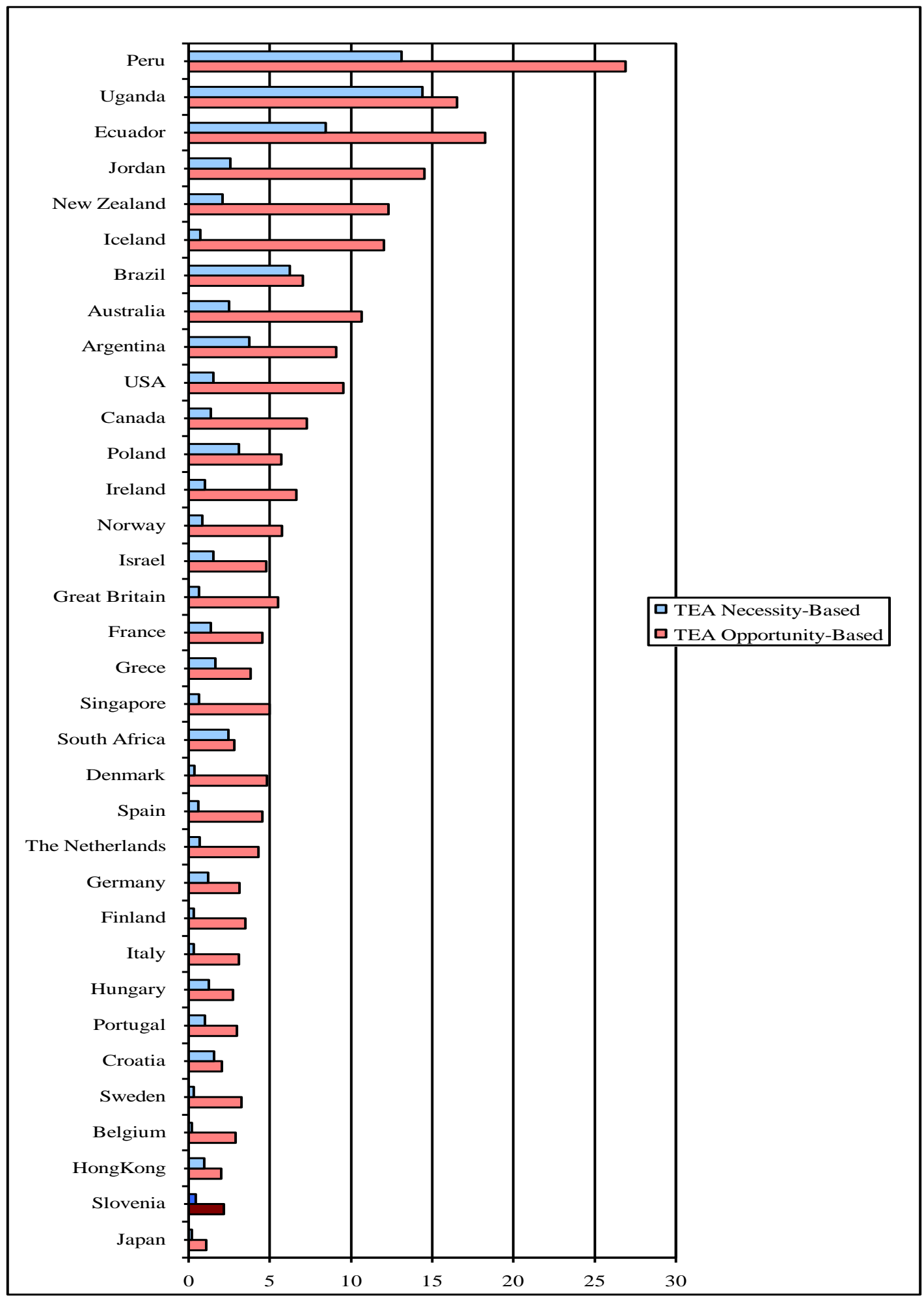

Source: GEM, Slovenia 2004, 2005. 
In spite of the fact that Peru, Ecuador and Uganda have the highest TEA index, the quality, not just the quantity should be considered. Moreover, considering the fact that many nascent entrepreneurs do not survive and prosper, the TEA index often cannot show the real entrepreneurial potential. On the other hand, the TEA index excludes businesses older than three years, as well as dynamic and knowledge-based, well-known enterprises and corporations which are the most important element enabling economic and social development of any country.

About 54 percent of those involved in creating and growing new firms claimed that they were pursuing a business opportunity for personal interest and at the same time they often worked in a regular job. These efforts are referred to as opportunity entrepreneurship, reflecting the voluntary nature of participation. In contrast, about 43 percent reported they were involved because they had no better choices for work.

Such efforts are referred to as »necessity entrepreneurship, reflecting the individual's perception that such actions present the best option available for employment but not necessarily the preferred one. The remaining 3 percent involved in new business activity reflect other motivations.

In terms of opportunity entrepreneurship the leading countries are Peru, Ecuador, Uganda, Jordanian, New Zealand, Iceland, Australia, USA, Argentina and Canada. As for necessity entrepreneurship the leading countries are mainly the less developed ones, such as Uganda, Peru, Ecuador, Argentina Poland, Jordan, and South Africa. Northwestern European countries have a very low percentage of necessity entrepreneurship. According to the general TEA index classification, Slovenia ranked rather low - between 28 and 33 among 34 countries (Figure 1).

Considering the relationship between necessity-based and opportunity-based TEA index, the largest number of people are forced into entrepreneurial career in South Africa, Brazil and Uganda, in Europe we can list the following countries: Croatia, Hungary and Poland. The highest percent of opportunity-based entrepreneurial activity can on the other hand be found in Denmark, Iceland and Spain.

When choosing or thinking about entrepreneurial career, people respect opportunity costs. In less developed countries, it is obvious that potential entrepreneurs cannot lose a lot, especially if they are unemployed and selfemployment is the only chance for making a living. In developed countries (e.g. Portugal, Italy, Belgium, Japan, and Slovenia), people compare advantages of being employed with advantages of being self-employed and they do not want to take risks. Welfare state discourages early-stage entrepreneurial activity, especially necessity-based. Correlation between Entrepreneurial Activity by Country (TEA index 2004, the scale varies from 0 to 16) and Employment Protection Index (the right $\mathrm{X}$ axe) is shown in Figure 2.

In Figure 2 it is clearly demonstrated, that while Employment Protection Index decreases, the TEA index, representing early-stage entrepreneurial activity is increasing, and vice versa. Nevertheless, there are not many benefits from necessity-based entrepreneurship, as these firms usually remain micro businesses, with significant lack of tensions for growth, development, and knowledge-based orientation. Opportunity-based start-ups on the other hand have much better chances to survive as well as to become dynamic, fast growing enterprises, thus enabling sustainable economic growth.

Findings mentioned above can also be proved by another interesting correlation. Analyzing entrepreneurial activity by country (TEA index) and GDP per capita, we came to the conclusion that the relationship between these two variables can be presented with $\mathrm{U}$ - parabola (Figure 3), which has an extreme at GDP p. c. USD 30,555.

Slovenian position shows backwardness in rising nascent enterprises. On the other hand, there are some reasons (which will be further discussed in detail) we should take in consideration when fostering entrepreneurial activity in Slovenia. Big companies in transition, having their own problems for example, can not act as supportable corporations enabling small-businesses to survive (e. g. as subcontractors etc.). Being somewhere between developing and developed countries, Slovenia is a good representative for U-parabola, expressing low nascent entrepreneurial activity. 
Figure 2: Entrepreneurial Activity By Country (TEA Index 2004) And Employment Protection Index

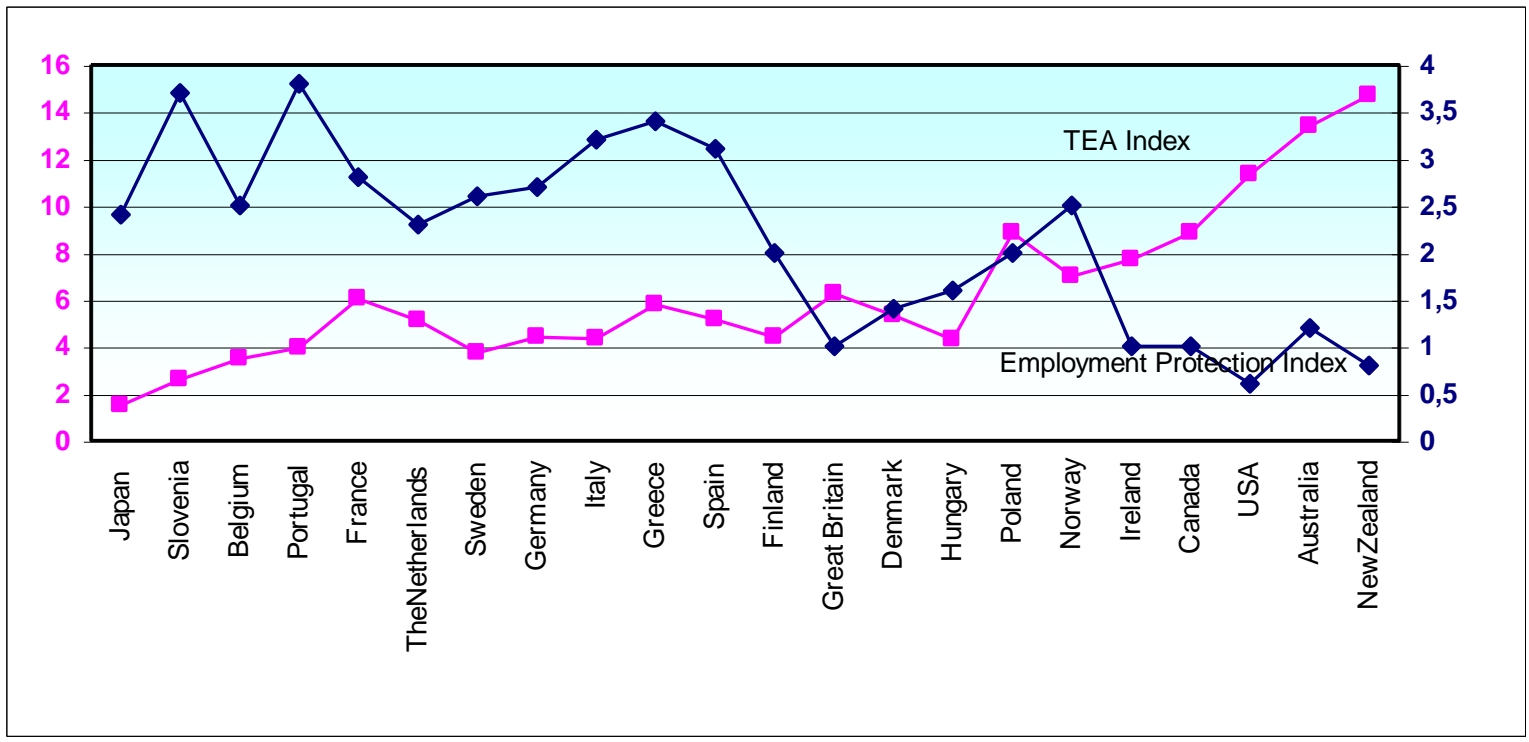

Source: GEM, Slovenia 2004, 2005.

Figure 3: Entrepreneurial Activity By Country (TEA Index) And GDP Per Capita

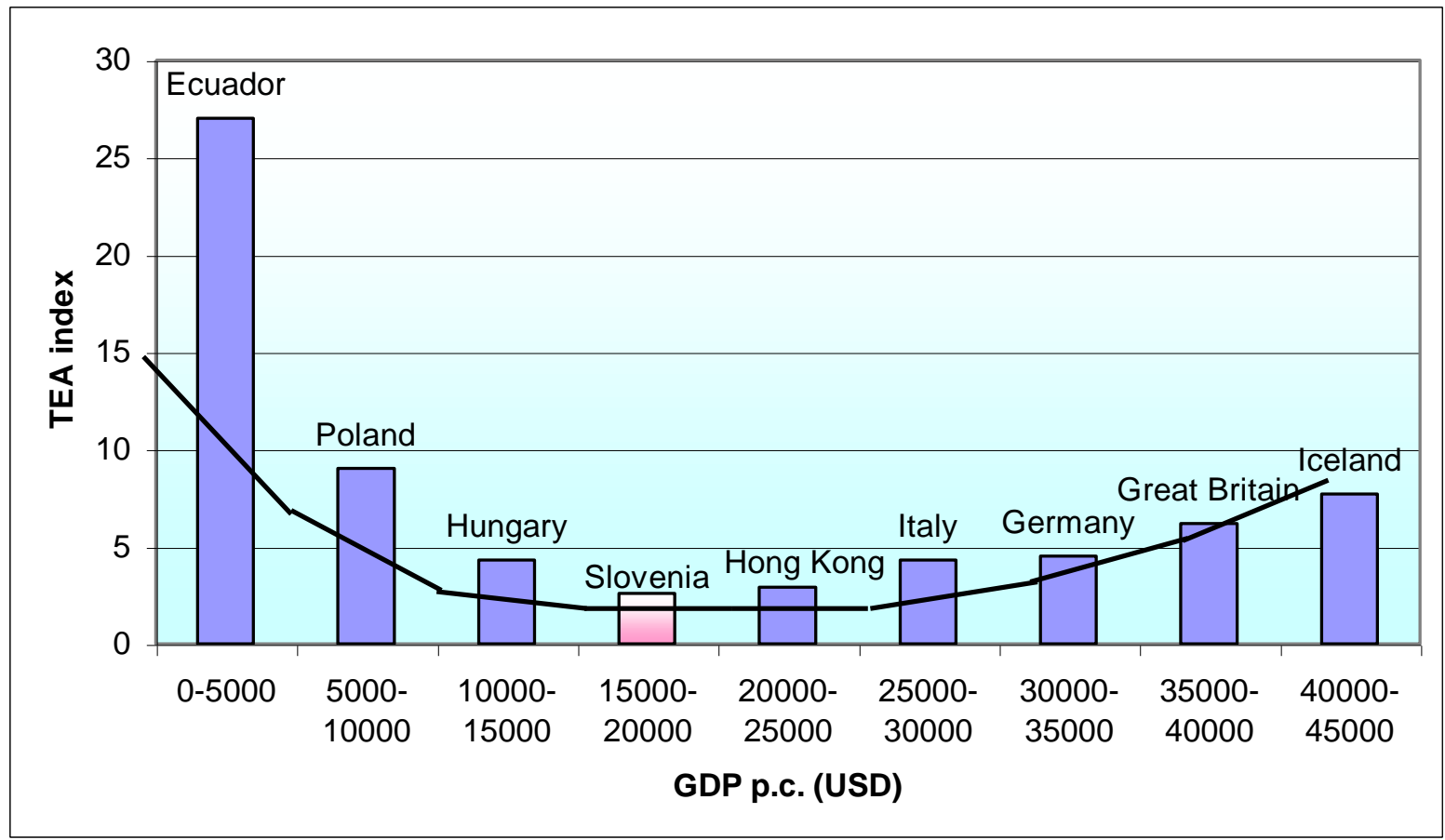

Source: GEM, Slovenia 2004, 2005. 
Developing countries (e.g. Peru, Ecuador, and Uganda) have a very high TEA index, which is decreasing with higher GDP p.c. up to USD 30,555. Developed countries (having GDP p.c. more than USD 30,000) report higher rates of entrepreneurial activity - the TEA index increases accordingly with economic development and higher GDP p. c. Examples are shown in Table 1.

Table 1: Countries And Entrepreneurial Activity (Considering The TEA Index) In Correlation With GDP p.c.

\begin{tabular}{|l|l|}
\hline GDP p.c. (USD) & Countries And TEA Index \\
\hline $0-5,000$ & Peru (40.34), Uganda (31.64), Ecuador (27.24), Jordan (18.26) \\
\hline $5,001-10,000$ & Argentina (12.84), Poland (8.83) \\
\hline $10,001-20,000$ & Israel (6.62), Greece (5.77), Slovenia (2.60) \\
\hline $20,000-30,000$ & Singapore (5.69), Spain (5.15), Italy (4.32), Hong Kong (2.97) \\
\hline More than 30,000 & Canada (8.85), France (6.03), Great Britain (6.25), USA (11.33), Iceland (13.57), Ireland (7.70) \\
\hline
\end{tabular}

Source: GEM, Slovenia 2004, 2005.

High Total Entrepreneurial Activity Index in less developed countries is often reached through significantly high necessity-based entrepreneurial activity - as the consequence of low standard of living, low employment protection index and poor chance for making a living. Rather low TEA index in developed countries, accompanying higher GDP p.c. (up to USD 30,000) indicates better living conditions and welfare state, which guarantee social and economic security to inhabitants. People are not forced into entrepreneurship to make a living. Developed and rich countries express high TEA index, which is achieved mostly by having high rates of opportunity-based entrepreneurship. Countries having GDP p.c. more than USD 30,000, have already established conditions enabling entrepreneurial development among start-ups, as well as among dynamic enterprises. Potential entrepreneurs in these countries can afford risks, neither individuals nor society face a lack of capital. Relatively high TEA indexes in developed countries are achieved mostly with high levels of opportunity-based entrepreneurial activity. Opportunitybased enterprises are more stable, the mortality between them is lower, and they usually grow fast. Moreover, highly developed countries mostly promote entrepreneurship, spread entrepreneurial culture among their citizens and foster fast-growing, knowledge-based enterprises to compete even more successfully on the global market.

Considering the facts mentioned above it is not wise just to promote entrepreneurship and to force people into entrepreneurial career. Having millions of nascent entrepreneurs involved in business due to necessity and having little chances to survive and grow does not contribute to economic growth. Knowledge-based economy needs new ideas to be commercialized; it needs dynamic, knowledge-based enterprises.

\section{ENTREPRENEURIAL ACTIVITY IN SLOVENIA}

During the 1990s, Slovenia experienced a wave of entrepreneurship, bringing the number of incorporated businesses up from 4,112 in 1989 to 56,473 in 1999 and the number of sole proprietors from 35,479 in 1991 to 65,346 in 1999 (Statistical Yearbook of Slovenia, 2001). In spite of the growth of new venture creations, some important structural problems are still hampering Slovenian economic competitiveness. There are three weaknesses: (1) the new private ventures are still mostly micro businesses and their growth is very slow; consequently, there is lack of core small businesses in the size-class of $11-50$ employees, (2) the current GDP p. c level in Slovenia indicates that the service sector is still underdeveloped and (3) the share of innovative, new technology - based firms is virtually negligible. After 1994, the spontaneous wave of entrepreneurship was exhausted and the entrepreneurial pool was not strong enough for high - tech and growth oriented start - ups. Considering the crucial influence of entrepreneurship on growth, new job creation, innovation and general prosperity, we can confirm the first hypothesis that "Slovenia needs to expand its entrepreneurial activity in general, especially dynamic and high-tech entrepreneurship to compete successfully on the European market". 


\section{FACTORS - INFLUENCING SLOVENIAN ENTREPRENEURIAL REALITY}

\section{Slovenia - A Welfare State}

Extremly low necessity-based TEA index is undoubtably one of the reasons for low general TEA index in Slovenia. As we mentioned before, considering opportunity-based and necesssity-based TEA index, there are significant differences between countries. In Iceland, there are almost 17 opportunity-based nascent entrepreneurs per one necessity-based nascent entrepreneur. In Brazil and Uganda, this proportion is almost equal. In Slovenia, the ratio is 5:1, which place Slovenia somewhere in the middle of the table (Table 2).

Table 2: Position Of Slovenia, Considering "Opportunity: Necessity Proportion"

\begin{tabular}{|l|c|c|c|c|c|}
\hline Country & $\begin{array}{c}\text { General TEA } \\
\text { Index }\end{array}$ & $\begin{array}{c}\text { Oportunity-Based } \\
\text { TEA }\end{array}$ & $\begin{array}{c}\text { Necessity-Based } \\
\text { TEA }\end{array}$ & $\begin{array}{c}\text { Proportion } \\
\text { 0pportunity vs. } \\
\text { Necessity }\end{array}$ & Rank \\
\hline Iceland & 13.57 & 12.04 & 0.72 & 16.72 & 1 \\
\hline Belgium & 3.47 & 2.9 & 0.19 & 15.26 & 2 \\
\hline Denmark & 5.31 & 4.82 & 0.37 & 13.03 & 3 \\
\hline Finland & 4.39 & 3.50 & 0.33 & 10.61 & 4 \\
\hline Sweden & 3.71 & 3.26 & 0.33 & 9.88 & 5 \\
\hline Italy & 4.32 & 3.08 & 0.33 & 9.33 & 6 \\
\hline Slovenia & $\mathbf{2 . 6 0}$ & $\mathbf{2 . 1 7}$ & $\mathbf{0 . 4 3}$ & $\mathbf{5 . 0 5}$ & $\mathbf{1 8}$ \\
\hline Peru & 40.34 & 26.92 & 13.09 & 2.06 & 29 \\
\hline Poland & 8.83 & 5.71 & 3.11 & 1.84 & \\
\hline Croatia & 3.73 & 2.04 & 1.57 & 1.30 & 30 \\
\hline South Africa & 5.40 & 2.80 & 2.44 & 1.15 & 31 \\
\hline Uganda & 31.64 & 16.52 & 14.4 & 1.15 & 32 \\
\hline Brazil & 13.48 & 7.04 & 6.22 & 1.13 & 33 \\
\hline Source & & & & 34 \\
\hline
\end{tabular}

Source: GEM, Slovenia 2004, 2005.

Potential entreprenurs in rich countries are not forced in entrepreneurial career, as they usually have a job and capital for the beginning. Moreover, there is a strong net of social security in many developed countries. Social security accompanied with employment protection and resulting in higer oportunity-costs of entrepreneurial career, discourage entrepreneurial activity. This fact is also shown in Figure 2. Countries with a low employment protection index have a relatively high TEA index, and vice versa (Bosma N., Wennekers S., 2004). The higher percent of GDP is spent on social security in a country, the lower is people's involvement in entrepreneurship. Nevertheless, highly developed knowledge-based economies do not even need "self-employment"-oriented businesses, as they have huge corporations, enabling sustainable economic growth and social stability, they still force opportunity-based entrepreneurial activity and creation of new, knowledge-based entreprises.

\section{Obstacles And Problems Of Slovenian Entrepreneurship}

Glas (1997) states many conditions (i. e. inhibitors), which have a negative impact on entrepreneurial activity in Slovenia. We can divide them into two groups:"soft elements", which mostly deal with entrepreneurial culture (and its elements) and "hard elements", which include general entrepreneurial conditions, mostly connected with government and non-government operations. We can list the following related obstacles: low level of innovation and R\&D, weak transfer of knowledge and technology from universities to practice, inadequate town-planning policy and programs, discouraging tax and financial policy, complicated administrative procedures, lack of physical infrastructure, entrepreneurial infrastructure, and necessary information, low adaptability of education system.

\section{Entrepreneurial Culture In Slovenia}

Culture in general reflects different social relations among people, social inheritance, including material objects and certain patterns of thinking, feeling, and acting, which were transferred from one generation to other 
(Vander Zander, 1993). People of the same nation usually have common or similar goals, motives, orientation and behavior. They share the same territory with specific characteristics, which also have an impact on people's habits and affect their character. In spite of the fact, that culture reflects the way of life of the majority, individuals can behave and react specifically, in their own way.

In the discussion of the entrepreneurial phenomenon, culture is important, as it reflects and determines certain standpoint and different point of view of individuals and people in general about fostering entrepreneurship (VernonWortzel, Wortzel, in Morrison, 1998). Cultural conditions can foster or hamper individuals to start a career as entrepreneurs. Entrepreneurially oriented society respecting entrepreneurial values (Morrison, 1998) acts as an incubator for new infant enterprises and thus encourages entrepreneurship. Society (e.g. Slovenian) that equals entrepreneurs with profit-makers and entrepreneurship with gain-seeking or speculating activity, on the other hand, inhibits entrepreneurial activity.

Entrepreneurial culture reflects a variety of social circumstances (e.g. history, political system, religion, ideals, ideology, tradition, customs, family, educational attainment of individuals, educational system in general, economy, beliefs), values, attitudes (e.g. towards the risk-taking, failure, joined capital, shared ownership etc), psychological characteristics (e.g. need for achievement, persistence, inventiveness, responsibility etc.) and patterns of behavior typical of entrepreneurs.

Entrepreneurial orientation usually reflects the awareness and understanding of long-term benefits of entrepreneurial activity. This is partly connected with personal attitude toward entrepreneurial career and entrepreneurship in general. Morrison (1998) describes entrepreneurial culture as domination of positive attitudes toward private enterprises, which enables and encourages entrepreneurial activity in certain society.

Domination of entrepreneurial basis, mentioned above, impacts the attitudes of society (e.g. state, media, and citizens) towards entrepreneurial activity and creates the foundations for entrepreneurial development.

"We can hardly say, that Slovenia has ever been an entrepreneurial society", says Glas (1997). The trend is partly connected with the Slovenian employment history of primarily farmers and craftsmen. In the past, most managers and industrialists were foreigners who left Slovenia after 1945. In addition, fifty years of socialism have not created a typical entrepreneurial environment and culture. The system blocked creativity and anchored the ideology of irresponsible egalitarianism. Glas (1999) emphasizes that besides "hard inhibitors" of entrepreneurship mentioned in Glas (1997) Slovenian culture with its egalitarianism, envy and low tolerance to failure cannot give the necessary support to fostering entrepreneurship.

Political and economic historical background, social tensions caused by standard of living differentiation, egalitarianism, low involvement of women entrepreneurs, weak connections and cooperation between entrepreneurs, low private savings, negative inclination towards risk-taking and sharing capital with partners, lack of team-work orientation, weak entrepreneurial experience possessed by entrepreneurs and psychological profile of Slovenian people, which will be discussed later in detail, are also significant obstacles for developing entrepreneurial society in Slovenia.

Ideology, attitudes and beliefs of most Slovene people do not support entrepreneurship. The social environment is not tolerant to the entrepreneurs who failed, so the Slovenes are afraid of failure and hardly take any risks. Attitudes towards savings are also specific; Slovenian people usually save to build a house or to buy a flat or a car. Some of them save for social security when getting old. They usually do not invest their money in business (Berk, 2000).

We can conclude that entrepreneurial culture in Slovenia is rather low. However, education could play an important role in developing entrepreneurial culture, as it has a long-term impact on personal profile of people. 


\section{Personality Traits}

An entrepreneurial opportunity needs to be realized by a good entrepreneur who turns opportunity into success. Timmons (1989) states some characteristics, which are possessed by successful entrepreneurs, for example: self-confidence, courage, commitment, determination, creativity, hard-work, resilience, optimism, modesty, high need to achieve, independence, communication skills and vision. Some authors (Sisan, 2000), for example, Zimmerer and Scarborough, Gray, Begley and Boyd, Kuehl and Lambing, Glas usually add internal locus of control, tolerance towards uncertainty and risk-taking, competitiveness and being ambitious.

We are aware of the fact that no one, including the most successful entrepreneurs, possesses all of above mentioned characteristics. Complementary skills and characteristics are combined by joining with partners.

On the other hand, it is obvious that possessing entrepreneurial characteristics is not a sufficient condition to start and run a firm successfully. Some researchers (Stevenson and Sahlman in Chell, Howarth, Brearley, 1991) were very critical towards psychological and sociological theories, dealing with personal characteristics of potential entrepreneurs. They stated that many successful entrepreneurs do not possess mentioned characteristics. Considering their findings, researchers (Petrin, Antoncic, 1995) developed a contingency approach - which includes the environmental conditions, stimulating entrepreneurial characteristics to be entrepreneurially-oriented - and transactional approach (dealing with social contacts and mutual cooperation between entrepreneurs within networks, thus enabling new firm creation). Similar approaches include constructivity approach by Kelly (in Chell, Howarth, Brearley, 1991) and interactivity approach by Chell, Howarth and Brearley (1991), highlighting impact of social environment on entrepreneurial activity.

In spite of the fact that the psychological and sociological theories do not give an adequate answer about the entrepreneurial personality, there is little doubt that entrepreneurial characteristics people possess can help create a base for entrepreneurial development.

Some of the characteristics mentioned above are inborn (for example energy or intelligence), others can be partly developed (Glas, 2000): health, emotional stability, inspiration capability, innovativity, creativity and personal values. Pedagogic circles round the world are using different tools and methods to develop creativity. Many researchers (Gray, 1998; Russell, 1994; Johnson in Petrin, Antončič, 1995; McClelland in Kilby, Livesay, 1995; Vahčič in Možina et al., 1994) found out, that education can play a significant role in systematic development of entrepreneurial knowledge and skills, as well as in developing entrepreneurial characteristics (Morrison, 1998, Gibb, 1994).

Empirical research of personality traits of Slovenian entrepreneurs showed that the most desired entrepreneurial characteristics (Begley, Boyd, 1995; Chell, Haworth, Brearley, 1991) including responsibility, working enthusiasm, endurance, initiative, self-confidence, creativity, and innovation are rated low (Musek, 1994). Vision, risk-taking, leadership, criticism and ethical values are ranked even lower. By analyzing Slovene people personality profile, Musek (1993) notices the following characteristics: (1) introvert orientation (the Slovenes are mostly cold, retained, not very sociable, but considerate and responsible, on the other hand), (2) psychotics (not tolerant, not sincere, aggressive, egoistic, dominant, ambitious, envious and jealous), (3) a great need to get approval and to excel, accompanied by low sense of mutual responsibility and cooperation (Musek, 1994), (4) neuroticism, relatively high level of self-aggressiveness and emotional instability, pessimism, external locus of control. Just (5) working enthusiasm and discipline, Slovene people possess (Musek, 1994), are characteristics typical of entrepreneurs.

We can conclude that the psychological profile of Slovenian entrepreneurs is closer to the profile of employees than to dynamic entrepreneurs - hypotheses 2 (Musek, 1994; Trstenjak, 1991).

But we are inspired by the fact, that most of desired entrepreneurial characteristics (responsibility, persistence, working enthusiasm, motivation, communication skills etc.) can be developed and improved by experience, practice and learning, especially within educational system (process). 


\section{The Educational Dimension}

The comparison with other countries shows that the educational level of Slovenian entrepreneurs and managers is lower than it is in other countries, which indicates, that Slovenia is still not focused enough on educating its active and potential entrepreneurs and managers. 73 percent of Slovene entrepreneurs mostly have finished vocational and secondary school; American entrepreneurs mostly (63 percent) have university or post-graduate education (Glas, Drnovšek, 1999, 2001, Sisan, 2000). Compared Slovene managers with American counterparts, the findings are similar (Vahčič, Glas, Petrin, 1998, p. 13). The trend is partly connected with the Slovenian employment history of primarily farmers and craftsmen. In the past, most managers and industrialists were foreigners who left Slovenia after 1945. In addition, fifty years of socialism have not created a typical entrepreneurial environment and culture. The recent level of entrepreneurial activity in Slovenia needs to be expanded, mostly by developing activities connected with up-to-date knowledge in the field of technology as well as in the field of business. Prosperity of hightech and fast growing enterprises can be achieved primarily by educating potential young entrepreneurs (GEM, 2001, page 17). We are not only facing lack of entrepreneurial and management knowledge but also lack of technological and organizational skills, as well as legal knowledge. If we exclude employees in leading positions and government employees, relatively low educational levels together with business illiteracy result in a small pool of entrepreneurial talents. In order to foster future growth of small businesses it is important to stimulate young generations to continue their education at the graduate level.

The influence of educational institutions on fostering entrepreneurial activity has already been proven. Entrepreneurial activity in a certain country is significantly positively related to entrepreneurial knowledge and qualifications (GEM, 2001, p. 23). Research shows that education is the most important factor influencing the growth of enterprises as well as the entrepreneurial activity in general. It also determines the development of entrepreneurial characteristics and behavior of people.

Education is however, related to the type of economic activity and expected firm's growth (GEM, 2001, p.17; Erikson, 2001); the percentage of entrepreneurs anticipating substantial growth was significantly higher (31 percent) in those with graduate experience. People with higher education are more open to team work and tend to join their capital or firm with partners, thus enabling the firm's growth. Educated entrepreneurs are more self-confident and are not afraid of failure. Lack of necessary skills and knowledge usually results in the fact, that Slovene enterprises mostly remain micro firms (very often based on self-employment).

We can conclude, that especially "dynamic entrepreneurship requires a higher educational level than Slovenian entrepreneurs posses". However, most Slovenian potential and active entrepreneurs lack the desired entrepreneurial characteristics. In addition, Slovenian entrepreneurs and managers have much lower education than their American counterparts. These two facts indicate that Slovenia should focus much more on entrepreneurial and managerial education in striving to become ideal entrepreneurial society in which entrepreneurship is the way of life for the majority of its population.

Considering the findings of different analyses dealing with synergy between education and entrepreneurial activity (Dragar, 1999, Glas, 2002; Hisrich, 1995; Hynes, 2001; Hytti, 2002; Timmons, 1994; Vahčič et al, 1998 etc.) we can recommend the following:

1. Entrepreneurial education should be involved at all levels of education, from the kindergarten up (Gibb, 1994, p. 32-36, Timmons, 1994, p. 18); Finland and Ireland for example, start with entrepreneurship programs at an early age.

2. Continuous education should be implemented through life-learning programs after finishing formal education (Hisrich, 1995, p. 183-186).

3. Entrepreneurial education should be spread from business - oriented schools and faculties to all others.

4. An interdisciplinary-oriented entrepreneurial incubator acting as a model for real enterprises should be established.

5. Entrepreneurial programs in Slovenia are separated and crumbled at different educational levels and not harmonized. They should be more extensive and spread through different educational levels. 
6. Entrepreneurial programs should be categorized under the following three headings: informative-oriented programs (learning to understand entrepreneurship and increasing the awareness of the entrepreneurship phenomenon), formative-oriented programs (learning to become an entrepreneur, developing entrepreneurial characteristics as well as increasing the entrepreneurial skills and knowledge) and finally a program which would support the implementation of entrepreneurial ideas in cooperation with the entrepreneurial incubator.

7. Teachers should be more flexible, student-centered methods should be implemented at all school subjects on a larger scale (teachers should be educated and trained, intending trainings in Slovenia, and international courses).

8. The cooperation with educational institutions abroad should be strengthened, thus enabling internationalization of programs and continuous development of teachers, professors and other instructors of entrepreneurial education.

9. Students should choose their mastery or doctoral thesis in cooperation with enterprises, working on real problems.

10. The implementation of the stated suggestions should be empirically tested.

\section{CONCLUSION}

In the paper we have clearly demonstrated that the level of entrepreneurship varies from country to country, mostly depending on its economic development, and the differences should be reflected in the specific economic development policy, training programs, curricula structure, and the methods of training and evaluation adopted.

Being in the middle between developing and developed countries (according to GDP p.c.) and having very low TEA index, indicates that Slovenia should work much more on fostering its entrepreneurial activity. A vision of becoming highly developed, knowledge-based society cannot be reached without increasing the birth rate of nascent entrepreneurs, as well as without sustainable growth of those, which have already built their image. There are some crucial criteria, which can be helpful in the process of continuous checking the entrepreneurial development policy achievements (Rebernik at al, 2005): (1) TEA index enlargement; (2) lower mortality between start-ups; (3) higher involvement of women entrepreneurs; (4) higher percentage of educated entrepreneurs; (5) increasing opportunitybased TEA index; (6) better perception of entrepreneurship in society, spreading entrepreneurial culture among people; and (7) qualitative and sustainable growth of enterprises, expressed by increasing economic value added index.

The Slovenian economic development policy is facing the challenge how to change the trend of decreasing TEA index and establish conditions which would encourage entrepreneurial activity including: (1) increasing the number of births of new enterprises following opportunities, and (2) enabling recent enterprises to commercialize ideas and achieving sustainable growth and development. On the other hand, there is no sense mass forcing people into entrepreneurial career, as the quality of entrepreneurship is more important than the quantity. In striving to become a learning society, Slovenia should concentrate on developing high-tech, knowledge-based, fast-growing enterprises, led by highly educated, ambitious entrepreneurs. Therefore it is important to utilize educational dimension as the prosperity of high-tech and fast growing enterprises can be achieved primarily by educating potential young entrepreneurs.

\section{REFERENCES}

1. Begley, Thomas M. and Boyd, David P.: Psychological Characteristics Associated with Performance in Entrepreneurial Firms and Smaller Businesses. V Livesay Harold C., ed.: Entrepreneurship and the Growth of Firms, Vol. I. Aldershot: Elgar, 1995. pp. 330-344.

2. Berk, K.: Drzava ne spodbuja varcevanja. Slovenski delnicar, Ljubljana, 5(2000), 37, pgs. 4. In Slovenian.

3. Birch, D.: Dynamic Entrepreneurship and Job Creation: Lessons from the US Experience for Central and Eastern Europe. The Hague: V Abell D.F. Koellermeier T.: Dynamic Entrepreneurship in Central and Eastern Europe, 1993, pp. 13-23.

4. Bojović, Vesna: Pomen podjetništva in inovativnosti pri prestrukturiranju gospodarstva: diplomsko delo. Ljubljana: Ekonomska fakulteta,1989. 50 pgs. In Slovenian.

5. Bosma, N. and Wennekers, S.: Illustration of the Relationship between Employment Protection and Total Entrepreneurial Activity in the European Union. In: Acs et al., GEM 2004 - Executive Report. Babson College and London Business School. p. 44. 
6. Burton-Jones, Alan: Knowledge capitalism. Oxford University Press Inc, New York, 1999, 237 pgs.

7. Chell, Elizabeth, Haworth, Jean, and Brearley, Sally: The Entrepreneurial Personality: Concepts, Cases and Categories. London: Routledge, 1991. 171 pgs.

8. Dragar, Aleš: Predlog za razvoj celovitega sistema podjetniškega izobraževanja in usposabljanja v Sloveniji: magistrsko delo. Ljubljana: Ekonomska fakulteta, 1999. 119 p. In Slovenian.

9. Erikson, Truls: Entrepreneurial Capital - The Emerging Venture`s Most Important Asset \& Competitive Advantage. V: Entrepreneurship research conference 2001. Babson: Babson College - Jonkoping International Business School, 2001. 8 pgs.

10. European Commission: Green Paper, Entrepreneurship in Europe, Brussels, 2003, 25 pgs.

11. Fostering Entrepreneurship. Paris: OECD, 1998. 286 pgs.

12. GEM, Slovenia, 2002. Finance, ponedeljek, 18. November 2002, st. 220, pp. 17-20. In Slovenian.

13. Gibb, Allan A.: The Enterprise Culture and Education. International Small Business Journal, 1994, pp.11 33.

14. Glas, M.: Entrepreneurship and culture: An International Perspective: Case of Slovenia. Ljubljana: Delovni zvezki Ekonomske fakultete, No. 43, 1997. 16 pgs.

15. Glas, Marisa and Drnovšek, Mateja: Small Business in Slovenia: Expectations and Accomplishments, Paper presented at RENT XIII workshop, London. 1999. 22 pgs.

16. Glas, Miroslav et al.: Podjetništvo - poskusni delovni zvezek. Ljubljana: Zavod Republike Slovenije za šolstvo, 2000. 74 pgs. In Slovenian.

17. Glas, Miroslav: Ocena pogojev za podjetništvo v Sloveniji. Osnutek za raziskavo GEM, Slovenija 2002. 12/12-2002-6/1-2003. In Slovenian.

18. Gray, C.: Enterprise and Culture. London: Routledge, 1998. 207 pgs.

19. Hisrich, Robert: Politika spodbujanja podjetništva v gospodarstvih v prehodu. Ljubljana: Slovenska ekonomska revija, letnik 46, 1995, št. 3, pp. 183-186. In Slovenian.

20. Hynes, Briga: Encouraging Entrepreneurial Behavior in Non Business Students - The Issues in Programme Design. V: $31^{\text {st }}$ European Small Business Seminar. ESBS 2001- An Enterprise Odyssey: Dublin, Ireland, 12. - 14. September 2001. Dublin: Dublin Institute of Technology, 2001. Abstract, 1 p.

21. Hytti, Ulla at al.: State-of-Art of Enterprise Education in Europe, Results from the Entredu project. Small Business Institute, Turku School of Economics and Business Administration, Finland. 2002. 60 pgs.

22. Morrison, A.: Entrepreneurship and Culture Specificity. Glasgow: University of Strathclyde, 1998. 14 pgs.

23. Možina, Stane et al.: Management. Radovljica: Didakta, 1994. 1072 pgs. In Slovenian.

24. Musek, Janek: Osebnost pod drobnogledom. Maribor: Zalozba Obzorja Maribor, 1993, pp. 21-41 and 313323. In Slovenian.

25. Musek, Janek: Psihološki portret Slovencev. Ljubljana: Znanstveno in publicistično središče, 1994. 195 pgs. In Slovenian.

26. Petrin, T. and Antoncic, B.: Podjetnistvo. Univerza v Ljubljani, Ekonomska fakulteta. Ljubljana, 1995. 109 pgs. In Slovenian.

27. Rebernik, Miroslav et al.: Podjetništvo na prehodu; Global Entrepreneurship Monitor Slovenija 2004. Maribor: Ekonomsko-poslovna fakulteta, Inštitut za podjetništvo in management malih podjetij, 2005. 72 pgs. In Slovenian.

28. Reynolds, Paul D., Camp, S. Michael, Bygrave, William D., Autio, Erkko, and Hay, Michael: Global Entrepreneurship Monitor: 2001 Executive Report. London: Babson College, Kauffman Center for Entrepreneurial Leadership, London Business School, 2001. 57 pgs.

29. Rusell, M. K.: Can Business Schools Produce Entrepreneurs. Stirling, Conference IntEnt 94, 1994. Pp. 388-400.

30. Setnikar-Cankar, Stanka: Vloga in pomen podjetništva kot dejavnika gospodarskega razvoja: doktorska disertacija. Ljubljana: Ekonomska fakulteta, 1993. 207 pgs. In Slovenian.

31. Sisan, Ana: Podjetniška kultura v Sloveniji: magistrsko delo. Ljubljana: Ekonomska fakulteta, 2000. 80 p. In Slovenian.

32. Smallbone, David: Supporting SME Development in Economies in Transition: A View from the West. Paper presented at the conference: Industrial Organisation and Entrepreneurship in Transition, Varna, Bulgaria, June 1995, 10 pgs.

33. Statistični letopis Republike Slovenije 2001. Ljubljana: Statistični urad RS, 2001. (Statistical Yearbook of Slovenia, 2001). In Slovenian. 
34. Timmons, Jeffry A.: Podjetništvo kot obvezno znanje. Ljubljana: Podjetnik, 1994, št. 8, p. 18. In Slovenian.

35. Trstenjak, Anton: Misli o slovenskem človeku. Ljubljana: Slovenska knjiga, 1991. 203 pgs. In Slovenian.

36. Vahčič, Aleš., Glas, Miroslav, and Petrin, Tea: Experiences with the Entrepreneurship Education in Slovenia. IntEnt98 - International Conference on Entrepreneurship Education - European Business School, 1998.16 pgs.

37. Vahčič, Aleš: Stanje podjetništva v Sloveniji. Economic and business review, vol.2, posebna številka, Slovensko podjetje v devetdesetih, 2000. pp. 49-59. In Slovenian.

38. Vander, Zander J. W.: Sociology: The Core. New York: McGraw-Hill, 1993. 316 pgs.

39. Vidovič-Tomanovič, Maja: Pomen malih in srednjih podjetij v Sloveniji pri vključevanju v Evropsko unijo. Bilten MMP, Ekonomsko-Poslovna fakulteta Maribor, št. 1, letnik 4, 1999. In Slovenian.

\section{NOTES}


NOTES 